WIENER SLAVISTISCHES JAHRBUCH, Band 50/2004, 153-170

(c) 2005 by Österreichische Akademie der Wissenschaften, Wien

РАДОСЛАВА СТАНКОВА (СОФИЯ)

\title{
Житията на хилендарските монаси Доментиян и Теодосий във виенските ръкописи и въпросът за появата на стила "плетение словес" в сръбската агиография от XIII в.
}

Настоящата статия е посветена на три проблема относно историята на хилендарските жития за св. Симеон и св. Сава: (1) кога са написани тези текстове (като се имат предвид данните от приписките, вероятно присъствали в протографите на виенските ръкописи); (2) кога е творил хилендарският монах Теодосий и каква е връзката му с другия хилендарски агиограф Доментиан; и (3) дали може да се говори за ранна поява на стила “плетение словес" в сръбската агиография от XIII в.

\section{1. ЗА РЪКОПИСИТЕ}

Предполага се, че житията на хилендарските монаси Доментиян и Теодосий за двамата сръбски.първосветци Симеон и Сава са писани през XIII в. Три сръбски ръкописа от Австрийската национална библиотека във Виена - Codd. slav. 25, 57 и 131 - са съхранили в най-голяма степен пълния им текст. Според данните в описа на Г. Биркфелнер (1975: 242-248) виенският ръкопис № 25 е продаден на Австрийската императорска библиотека от Вук Караджич през 1856/58 г., ръкопис № 57 - от Светислав Веркович през 1858 г. и най-ранният ръкопис № 131 - от Мина Караджич през 1887 г., след смъртта на баща й. Първоначално Дж. Даничич (1860) издава Теодосиевото житие за св. Сава, но неправилно го озаглавява като Доментияново, в препис от XVI в. Рс 26 от Белградската Народна библиотека (впоследствие изгорял на гарата в Крагуевац). Едва пет години покъсно същият автор издава истинските Доментиянови жития за св. Симеон и св. Сава по виенския ръкопис № 57 (Даничич 1865) ${ }^{1}$.

\footnotetext{
${ }^{1}$ Другите преписи на Доментияновите жития открити до сега бяха четири: 1. Сръбски ръкопис, донесен от Печ, в сбирката на Гилфердинг в Петербург, за който съобщава В. Ягич (1873). Според Мошин (1958: 414) той се датира от 1420/35 г. и е под № 54. В него е поместено житието за св. Сава (лл. 1-210), с приписка в края на ръкописа, че житието е писано през 1253 г.; 2. Един по-ранен фрагментен
} 
1.1 Виенският ръкопис № 57, до сега отнесен към XVI в., но по-вероятно произхождащ от началото на XVII век ${ }^{2}$, с изписан в полуустав на 338 лл. хартия. Има приписка, показваща произхода му от манастира Дечани, както и бележка от Св. Веркович затова, как е намерил ръкописа в “стара Сърбия" (предполага се в Серес, дн. гръцка Македония). Този ръкопис съдържа Доментияновото житие на преподобния Симеон Мироточец за 13-ти февруари (лл. 1r-121r) със заглавие Мца фє

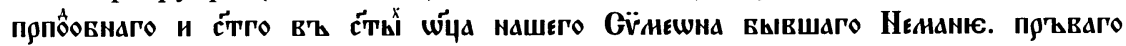

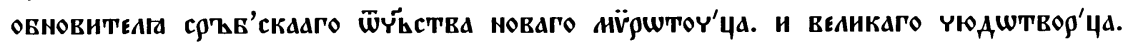

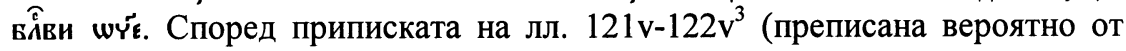
протографа на текста) се предполага, че житието е написано през 1264 г. След нея е поместено Доментияновото житие за архиепископ Сава за 14-

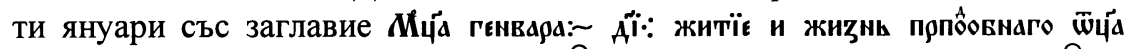
нашеГо. И Б́гоноснаго наставника. все се९̆

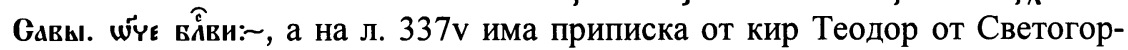
ския прот, която според изследователите ${ }^{4}$ посочва времето и мястото на написване на това житие - Карея, 1243 г. Ръкописът завършва с непълен тропар за св. Сава за осми глас (л. 338v).

1.2 Виенският ръкопис № 25, пак датиран към XVI в., но несъмнено по-късен 5 , е изписан в полуустав и сръбски правопис на 245 лл. хартия. В

препис на житието датиран от 1340 г. (1 л. харт., Университетска библиотека в Белград, Ћоровић, ФГм. 6). 3. Пълен ранен препис на житието за св. Симеон от Доментиян има в Хилендарския сборник с жития от 1370/75 г. (лл. 1-96) със запис на писара монах-тах Марко (Белград, НБС № 17, 326 лл. харт.), в който са поместени още Теодосиевото житие за св. Сава и Теодосиевата обща похвала за св. Симеон и св. Сава, както и препис на Хилендарския типик на св. Сава (ЩавлянинДжорджевич, Грозданович-Паич, Цернич 1986: 28-29). 4. Т. Йованович (2000: 193-201) открива друг ранен препис от Доментияновото житие за св. Сава в сборник, датиран от 80/90-те години на XIV в. (Букурещ, РАН, № 134), пак с частичен препис от Хилендарския типик и Теодосиевата похвала за св. Симеон и св. Сава. Има предположение, че в началото на този ръкопис е било поместено и Теодосиевото житие за св. Сава, но в съкратен вид (Юхас-Георгиевска 1995: 126). Скоро стана известен още един препис на Житието за св. Симеон от Доментиян в в сръбски ръкопис от третата четвърт на XIV в. (ОГНБ, сбирка на Григорович № $1 / 97$, лл. 1-157), също с хилендарски произход и с Хилендарския типик на св. Сава (подобно на НБС № 17, срв. Сводный каталог славяно-русских рукописных книг, хранящихся в России, странах СНГ и Балтии, ХІV век, выпуск 1, Москва 2002, 484-486: № 333).

2 Водните знаци имат по-късни съответствия: например едноконтурната котва в кръг, с детелина на върха, на лл. 9-12 може да се сравни със знак от 1630 г. в ръкопис на манастира Савина (Станкович 1998: 329, № 63), но контрамарките в двата ръкописа са различни.

${ }^{3}$ В приложението давам приписките във виенските ръкописи, копирани от протографа, заедно с приписката от Петербургския ръкопис (Гильф. 54), според изданието на В. Ягич (1873: 11-12).

${ }^{4}$ В. Ягич (1873), П. Сречкович (1898), Вл. Чорович $(1921,1936,1965)$, Др. Костич (1933), М. Динич (1959), П. Попович (1959), Дж. Трифунович (1963), М. Кашанин (1975: 152-177), Св. Радойчич (1979) и Д. Богданович (1980:154-159).

${ }^{5}$ Водният знак корона с двойно дъно, 9 зъбци, звезда и полумесец на върха (л. 25) съответства на знак от 1675 г. (Станкович 1998: 334, № 79), но контрамарките 
него е поместено Теодосиевото житие за св. Сава (лл. 1r-156r; текстьт е същият като текста във виенския ръкопис № 131) ${ }^{6}$. На лл. $156 \mathrm{r}-184 \mathrm{r}$ следва Теодосиевата обща похвала за двамата светци (със заглавие Тогоӝв ๑юю-

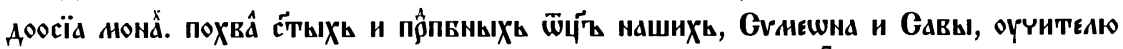
ср'ъп'скою, влагослови шч́; ; срв. текста в ръкопис № 131) ${ }^{7}$, а след приписката на лл. $185 \mathrm{r}-245 \mathrm{r}$ се намира Житието за св. Симеон от Доментиян (без начало, тъй-като липсват първите два листа), съвпадащо с текста в ръкопис № 57.

1.3 Най-ранният виенски ръкопис № 131 , датиран от Я. Пролович (1983: 203) от 80-те години на XIV в. ${ }^{8}$, не е издаден. Ръкописът е от 245 лл. хартия, сръбски правопис, полууставно писмо, атрибутиран към преписваческата дейност на хилендарския писар Йов (Пролович 1986: 203 и Църнич 1981). В него са налице преписите на Теодосиево житие за св. Сава (лл. $1 \mathrm{r}-149 \mathrm{v}$, неправилно отбелязано и в описа на Г. Биркфелнер като Доментияново) и на Общата похвала за св. Симеон и св. Сава от Теодосий (лл. 150r-176v) ${ }^{9}$. Следват още патристични поучения и Апокалипсис на Методий Патарски (лл. 191r-244v). Има и оригинална приписка от първия сръбски патриарх Паисий Яневац с данни: Печ, 1647 г. (л. 245r).

отново са различни. Затова смятам, че ръкопис slav. 25 би трябвало да се отнесе към последната четвърт на XVII в.

${ }_{6}^{6}$ Теодосиевото житие за св. Сава е запазено още в цитирания вече ръкопис от НБС № 17 и в пет ръкописа от XVI в. - НБС № 32, ПБ № 128, СЦ 18 (Мошин 24), ЈАЗУ (Ћир. фгм. 10), Плевля № 34 и в един от XVII в. - НБС № 54 . Два ръкописа с преписи на житието са изгорели - НББ № 26 (сборник от XVI в., в който е имало и житие за св. Йоан Златоуст) и НББ № 633 (сборник от XVI-XVII в., където е била и Теодосиевата служба за св. Симеон и св. Сава). Най-ранният Теодулов препис на Житието за св. Сава от Теодосий е бил от първата половина на XIV в. (Санкт Петербург, РНБ, F. XVIII. 34 и Белград, Архив на САНУ № 6317 - вж. Трифунович 1973: 3-9 и 1978).

${ }^{7}$ Теодосиевата похвала за св. Симеон и св. Сава най-напред е частично издадена от В. Ягич (1873: 19-20) по ръкопис № 55 от сбирката на Гилфердинг (с произход от манастира Сопочани, датиран от 1526 г. - за идентификацията вж. Йованович 1973: 703). По-пълно е изданието на Ст. Новакович (1879: 163-180) по руски препис на Тимотей Йованович от 1780 г. (в РГБ, Москва, Хлуд. № 212). Третото издание на текста на похвалата е на С. П. Розанов (1911) по ръкопис от края на XV в. (Москва, ГИМ, Синод. № 635), а най-ранният препис на Похвалата е издаден от Т. Йованович (1973) по препис на монаха тах Марко от 1370/75 г. в хилендарския по произход сборник с жития (днес Белград, НБС № 17). Той посочва всички известни дотогава ръкописи освен виенския № 131, който, като се изключи иззгубеният Теодулов препис, е най-ранният препис.

${ }^{8}$ Проверката на водните знаци категорично подтвърждава старинността на ръкописа и датировката на Я. Пролович: три от водните знаци (льк и стрела - л. 159; двурог - л. 198 и тризъбец - л. 232) напълно съответстват на знаците в четириевангелие от манастира Савина, датирано от 1375 г. (Станкович 1998: 340, 343, 361 - №№ 93, 105, 155)

\footnotetext{
${ }^{9}$ Вж. още Трифунович 1965 a.
} 


\section{2. ЗА АВТОРИТЕ}

2.1 Днес най-разпространено е мнението, че плодовитият хилендарски книжовник Теодосий е живял на границата между XIII и XIV в. (вж. Подскалски 2000: 376), но неговите произведения отразяват настъпващите развойни промени в старата сръбска литература през XIV в., свързани с въвеждането на Йерусалимския типик (Богданович 1978).

П. Й. Шафарик (1831), който за пръв път въвежда в обращение името му, го определя като автор от XVII-XVIII в.

Пръв преглед по въпроса, кога е живял Теодосий, прави Ст. Станоевич през 1929 г., като посочва мненията: - на Дж. Даничич (1860), че Теодосий е преработил Доментияновото житие за св. Сава през първата половина на XIV в.; - на В. Ягич (1867: 178, 1873: 19), който определя Теодосий като автор от XIII в.; - на Ст. Новакович (1879: 161-162), който пък мисли, че с голяма вероятност Теодосий е живял по времето на цар Душан през XIV в.; - на Св. Вулович (1885: 106, 1894: 245-246), който открива Теодуловия препис ${ }^{10}$ и определя периода, когато е живял Теодосий към края на XIII в.; - на П. Сречкович (1898), който смята, че Теодосий е бил връстник на Доментиян; - на П. Протич (1897: 71-72), който прецизира датата на написване на житието за св. Сава между 1322 и 1336 г. - и на М. Башич (1924: 17-18), който обобщава, че Теодосий е живял през втората половина на XIII в. и началото на XIV в. Самият Ст. Станоевич (1929: 204) пък определя годината 1292 за terminus post quem non, като според него през тази година започва творческият път на монаха Теодосий.

След Станоевич, М. Бойчевич (1939) определя Теодосий Хилендарски като книжовник от средата на XIV в., а Вл. Мошин (1939) търси Теодосий между хилендарските йеромонаси (той е наречен “кү९”, подобно на Теодул), като посочва, че е споменат за пръв път през 1316 г., а за последен през $1347 / 48$ г. в атонските документи.

Нов преглед на “Теодосиевския въпрос" сред изследователите от XX век е направен от И. Брайович (1984: 253-254), която цитира мненията на Дж. Сп. Радойчич (1954), Дж. Трифунович $(1970,1978)$ и Д. Богданович (1980) и стига до извода, че Доментиян и Теодосий са били съвременици за един кратък период от време, а написането на произведенията му би трябвало да се отнесе в самия край на XIII в. и първите десетилетия на XIV в. Последните изследвания на И. Шпадиер (2000) представят Теодо-

${ }^{10}$ За пръв път за Теодуловия препис споменава Св. Вулович през 1885 г. в писмо до И. Руварац (вж. Радойчич 1954: 18, бел. 36 и 37). Ръкописът е донесен от Хилендар в Белград през 1896 г. за издаване на текста. Трябвало е да бъде преписан от Др. Костич, но след смъртта на проф. Дж. Джорджевич през 1898 г. ръкописьт е изчезнал от работната му маса (Радойчич 1954: 18, бел. 37, срв. и Трифунович 1978). Й. Иванов (1932: 475-479) публикува откъс от друг ранен препис, който той е намерил в Лесновския манастир и е датирал към началото на XIV в. За този ръкопис повече данни не са известни. 
сий Хилендарски като “велики песник и велика загонетка српског средњег века”. Като анализира преписи на Теодосиевите произведения в два хилендарски сборника (Хил. 461 от XV в., с фрагмент от Теодосиевото житие за св. Сава, и Хил. 479 от XV-XVI в., с житието и службата за св. Петьр Коришки), тя не успява да защити тезата, че Теодосий е автор от XIII в.

Проблеми пред изследователите поставя също и датирането на второто житие, приписвано на Теодосий - Житието за св. Петър Коришки (вж. Новакович 1879 и 1884, Костич 1934). Оспорва се дори авторството на Теодосий (Ангелов 1983: 74).

2.2 За Доментиян се смята, че е роден в началото на XIII в. и преди да отиде в Хилендар е бил монах в манастира Жича, а в светогорския сръбски манастир е стигнал до сан йеромонах. Между 1243 и 1254 г. е бил духовник в Карейската килия, а по-късно в Пирга "Св. Преображение", когато през 1263 г. е поръчал на Теодор Граматик да препише Шестоднева на Йоан Екзарх. Предполага се, че преди това е съпровождал свети Сава в пътуванията му до Йерусалим и Палестина (1233/35 г.). Починал е в Хилендар, но не е известно точно кога.

Най-приемливо изглежда мнението на М. Динич (1959), че Доментиян е написал житието за св. Сава още през 1243 г. по времето на крал Владислав. Според П. Попович (1959) в текста става дума именно за историческите събития от времето на крал Владислав, а за владичеството на крал Урош се споменава в самия край на текста. Житието за св. Симеон Доментиян е написал близо двадесет години по-късно, през 1264 г., по поръчка на крал Урош I (1243-1276 г.), наследника на Неманичите (срв. Подскалски 2000: 365).

\section{3. ЗА ПРОИЗВЕДЕНИЯТА, ТЕХНИЯ ЖАНР И СТИЛ}

3.1 Най-вероятно Теодосий е писал житието за св. Сава през 1292 г., т. е. близо 50 години по-късно от Доментиян. Това обстоятелство се свързва с обширното заглавие на неговия текст и дава повод за различни тъл-

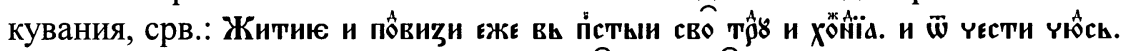

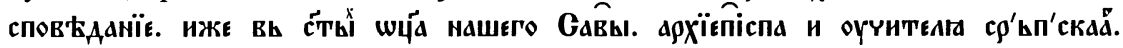

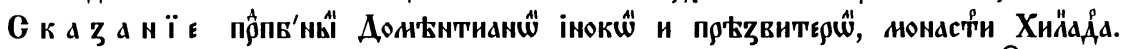

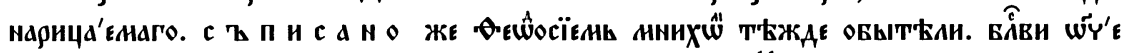
(ръкопис № 131, срв. и Новакович 1879: 115) ${ }^{11}$. Така Теодосий бива определян от Чорович (1936: 38) като компилатор на Доментиян.

Според Дж. Сп. Радойчич (1954: 15-17) заглавието би трябвало да се тълкува в смисъл, че Теодосий е бил по-млад от Доментиян и не е бил пи-

\footnotetext{
${ }^{11}$ Срв. със заглавието във виенския ръкопис № 25: С ка зан о пр̆пннй Аомєн-

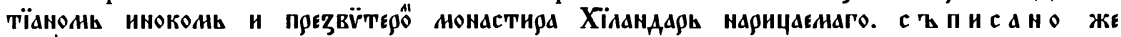

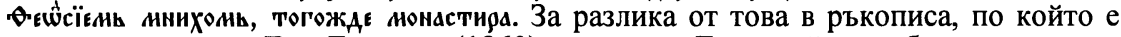
издал това житие Дж. Даничич (1860), името на Теодосий не е било споменато (вж. Радойчич 1954: 17).
} 
сател, а само преписвач. Н. Радойчич (1956: 7-16) от своя страна тълкува заглавието като свидетелство за съвместна дейност на двамата книжовници, но и поставя въпроса, защо е било необходимо да се пише ново житие.

По-приемливо е заключението на М. Кашанин (1975: 200), че Доментиян е разказал за живота на св. Сава и Теодосий е оформил ново житие. Понеже при двамата агиографи историческият и биографичният материал е сходен, но формата на изложение е различна.

Д. Богданович (1980: 173) смята, че Доментияновото житие е било основен извор за Теодосий, но той така го преработва, че то може да се приеме за нов текст: простият, жив и експресивен стил на Теодосий се противопоставя на монументалната тържествена риторика на Доментиян (Богданович 1980: 172). Теодосий предпочита нарацията пред риторичната възхвала на светеца, подчертава психологизма на личността, а не абстрактната идея (Кашанин 1975: 198) и дори вместо да славослови осъжда нравите на средновековното общество (Радойчич 1931: 9).

В контекста на формиращия се култ към първосветците Симеон и Сава в старата сръбска книжнина от XIII в., допълването и неколкократното написване на жития за всеки един от тях е основна специфика на литературния развой. На принципа на концентрично натрупване ${ }^{12}$ се създава и сборникът на архиепископ Данило II (Житија краљева и архијепископа српских - ЖКАС) като своеобразно продължение на традицията от предходния век да се репродуцират жития за сръбските владетели и архиепископи, но чрез допълване на текстовете и добавяне на нови светци. Архиепископ Данило продължава делото на Доментиян и Теодосий, но не пише жития за св. Симеон и св. Сава, а започва сборника с житие за крал Урош (вж. Чорович 1921: 22).

3.2 Доментиян е високообразован книжовник, апологет на християнската доктрина и тълкувател на монархическата религиозна идеология в сръбската средновековна книжнина (но няма данни да е произхождал от Неманичката династия). За разлика от Теодосий той не е писал химнографски произведения, но в Житието му за св. Сава е поместена дълга риторична похвала за двамата светци ${ }^{13}$.

Житието за св. Сава от Доментиян (ЖСД) е обемно пространно житие от типа на византийските риторични жития. Предназначено е не само за публично четене на датата на светеца, но и за индивидуално четиво.

${ }^{12}$ Под "принцип на концентрично натрупване" разбирам специфичната особеност на сръбската агиография да се натрупват или наслагват върху една тема или един житиен образ нови епизоди, библейска аргументация или агиографски топоси, натоварени с нови идейни тенденции, които да се възпроизвеждат във всеки следващ текст със същата тематика.

13 За творчеството на хилендарския монах Доментиян има богата литература вж. П. Сречкович (1898), Вл. Чорович $(1921,1936,1965)$, Др. Костич (1933), М. Динич (1959), П. Попович (1959), Дж. Трифунович (1963), М. Кашанин (1975: 152-177), Св. Радойчич (1979) и Д. Богданович (1980: 154-159). 
Текстът му е претрупан с библейски препратки и теологични интерпретации, които надхвърлят рамките на житийния разказ, но пък някои конкретни биографични данни за св. Сава са пропуснати в него (срв. Шмаус 1963 и Богданович 1970: 14). В ЖСД крал Владислав е наречен “благоверен”, “боголюбив”, “христолюбив” и “велик” владетел, а св. Сава, според установената вече сръбска традиция за назоваване, е наречен “земен ангел и небесен човек" (срв. Попович 1959: 209-211).

Двете Доментиянови жития за двамата сръбски първосветци св. Симеон и св. Сава са допълнени с нова библейска аргументация, добавена към известните вече библейски мотиви и топоси от предходните агиографски и химнографски творби за тях. Значително са разширени паралелите със старозаветните царе, повторени са топосите за добрия корен, за светилника, изпълнен с Христовата любов, за Света гора като райска градина, за медоносната пчела, за пречистващите сълзи и т. н. Житийните текстове са изпълнени в риторичен стил посредством синтактично-ритмични цялости с различни анафори, множество риторични въпроси и обръщения, изградени чрез градация, повторения и амплификации. И двете жития се характеризират с еднакви стилистични особености и целят обединяването на култа към двамата светци. Макар и монашески и светогорски, те са предназначени за кралския двор и са насочени към монументална идеализация на сръбската държавна доктрина за владетелския род.

В Житието за св. Симеон (ЖСмД) Доментиян внася същия стил и същата художествена интерпретация на фактите. Подобно на ЖСД, Неманя заповядва на Сава да пренесе неговите мощите в Сърбия и сам предрича мироточието им (Даничич 1865: 80); повтаря се и епизодът със съновидението на Сава, в което Неманя му казва, че е благословен от Бога (т. е. ще бъде канонизиран - Даничич 1865: 81-84); мироточивостта на мощите на св. Симеон още в Хилендар и предварителното прозрение на Сава за това (Даничич 1865: 85-86). Авторът дори добавя второ мироточие в Хилендар, от крака на изографисания на църковната стена образ на светеца (Даничич 1865: 88). Като светогорски монах Доментиян добавя и преработва агиографските епизоди, свързани с Хилендарския манастир, включва данни за вътрешното му устройство, споменава конкретни имена. Подробно разказва за мисиите на Сава в Цариград, Солун и Никея. Описва Египет, Палестина и Синай като очевидец. По отношение на данните за св. Симеон Доментиян се придържа изцяло към Житието за св. Симеон от Стефан Първовенчани (ЖССП). Има дори дословни съвпадения (вж. Чорович 1936: 15-22). ЖСмД е значително по-кратко от ЖСД, повтаря почти половината от ЖСД и около една четвърт от ЖССП.

Доментиян сравнява св. Симеон с византийските царе и го поставя в редицата на световните владетели. Според установената вече традиция, агиографът аргументира харизматичността на кралската власт с библейски цитати, топоси и реминисценции, свързва държавническата идеология 
с християнската доктрина, сравнява сръбския владетел със старозаветните родоначалници Аврам, Исак и Яков (срв. Дж. Даничич 1865: 14 и Хафнер 1964).

В риторичната похвала за св. Симеон, поместена в текста на ЖСмД се открояват внесените от Доментиян панигирични допълнения в житийния текст. Похвалата за св. Симеон е отделена от обширната и много впечатляваща (близо 10 страници от текста) обща похвала за св. Симеон и св. Сава. Изградена е чрез ритмично-синтактични редове от анафори, риторични въпроси и обръщения, сравнения, метафори и други риторични фигури, натрупана е с въпроси, епитети и обръщения. В текста на ЖСмД тържественият панигиричен патос се постига и чрез натрупване на еднозначни назоваващи определения за светеца под формата на обръщения, подкрепени с евангелски цитати. Те експлицитно илюстрират нанизването на синонимични наименования за светеца в обособен ред и изразяват на синтактично ниво назоваващия модус в агиографските текстове (вж. Измирлиева 1994).

3.3 Както вече стана дума, хилендарският монах Теодосий също пише похвала за двамата сръбски светци, но неговият текст е самостоятелно произведение на панигиричната проза (изд. от Новакович 1879: 164-180 и Розанов 1911: 185-209). В похвалата са използвани светлинни сравнения и метафората за духовната трапеза, подкрепени с Давидови псалми, които са установени вече като топоси за писмена идеализация на сръбските първосветци (вж. Станкова 2003). Теодосий отделя особено внимание на евангелските цитати за силата на словото по линията на преподобническата прослава на св. Симеон и св. Сава. Добавя евангелски реминисценции за страданието и търпението, като украсява героите си с мъченически венец или венец на славата (Новакович 1879: 166), елемент, който е иновация в сравнение с развития в химнографията топос за венцеплетението, но се вписва в нормативността на установената топика за възхвала на преподобническите добродетели на светците-мъченици.

В тази похвала св. Симеон отделно е назован като "вдджєнь ноүжь",

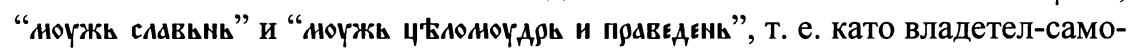
държец и като праведен мъж, просветил народа си в християнската вяра (Новакович 1879: 167-169), а Сава е похвален като равноапостолен: “нжє и апостольски сєго похвдлити" (Новакович 1979: 170). Приведени са и биографични данни, подкрепени с множество библейски цитати. Общата похвала е композирана като увод от риторични въпроси и същинска похвала с обръщение към слушателите (вратин) за достойна прослава на светците, със ЗаДължителните в риториката хайретични-анафори: "рАдоүи сє, Синєонє

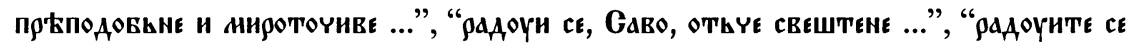

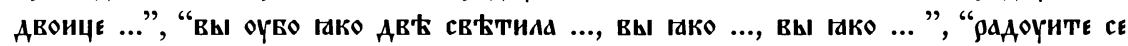
и вєсєлнтє сє ...” (Новакович 1879: 172-175). Теодосий назовава светците апостоли, пастири, пустинници, просветители и застьпници. Отделен па- 
саж е посветен на възхвалата им като праведници. Тези редове от назоваващи определения за св. Симеон и св. Сава следват логиката на търене на име за собствените домашни светци, превърнало се в топос за риторично изобразяване на двамата, поставящ ги на стъпалото “апостоли и пастири” (срв. Трифонова 1999: 12-16.) Текстът завършва с поучителен тон за назидание на монасите (вь мась сыныхь инокахь), който показва предназначението му за слушателска аудитория (Новакович 1879: 178-181, срв. Зееман 1988: 572-573).

3.4 Въпреки че творят в два различни жанра, чрез тържествено панигиричното звучене на произведенията си двамата хилендарски книжовници Доментиян и Теодосий целят двойна обща възхвала на първите сръбски светци - владетеля и архиепископа - и чрез нея - укрепване на държавническата идеология и народностното самосъзнание на сърбите. Доментиян и Теодосий градят похвалите си според правилата на средновековната риторика, позната на южнославянските книжовници още от предходните векове (Трифунович 1965б) чрез дълги ритмично-синтактични цялости (оформени с различни анафори), чрез чести библейски цитати и реминисценции, риторични въпроси и обръщения, чрез натрупване на разнообразни синонимни назоваващи определения.

При съпоставката между житието за св. Сава, писано от Теодосий, и това от Доментиян, се откроява краткостта и сбитостта на текста, простотата на езика и липсата на многословни отклонения при Теодосий, подобно на Житието за св. Симеон от Сава. Различията между двете хилендарски жития за св. Сава могат да се отнесат към различията между житията за св. Симеон от двамата му сина Сава и Стефан Първовенчани, но трябва да се има предвид, че двете хилендарски жития са писани според строгите норми на агиографската книжнина и са предназначени за двореца.

3.5 В края на XIII в. агиографията се налага като основен жанр в сръбската средновековна книжнина. Изказвани са множество мнения за заемки в стила на сръбските агиографи от този период и за развитие на жанра към панигирична тържественост. В основата на тезата за ранна поява на "висок" агиографски стил в средновековната сръбска литература са разработките на М. Мулич (1963, 1965а, 1965б, 1966, 1968). Според него исихастското схващане за величието на словото се проявява още в произведенията на Стефан Първовенчани. Честата употреба на синоними, натрупани със семантична нюансираност и нанизване на редове от синонимни сравнения са характерни за сръбските писатели Доментиян и Теодосий. Изводът на Мулич (1965б: 205) е, че още от края на XIII в. сръбските средновековни агиографи се стремят към засилване на експресивността и към по-голяма абстрактност на изказа. Според него стилът "плетение словес" се проявява при сърбите още през втората половина на XIII в. и началото на XIV в. в произведенията на агиографите Доментиян, Теодосий и Данило II, още преди Търновската книжовна школа в Бълга- 
рия и съчиненията на патриарх Ефтимий (Мулич 1968: 131 и 1975). Така той се противопоставя на наложилата се в науката теза, че стилът плетение словес възниква и се развива в България през XIV в. ${ }^{14}$.

Сред изследователите е станало общоприето мнението, че основните белези на този висок стил са: множество риторични амплификации, библейски цитати и аналогии с библейски персонажи и събития; натрупване на синонимни определения в градация и ритмизиран език, изграден чрез асонанси, алитерации и други стилистични похвати; сложни, дълги и често неразбираеми пасажи и словесни тиради, основани на паралели, сравнения, многосъставни словосъчетания, плеонастична символика и др. Всички тези формални стилистични белези са насочени към мистично внушение и усложнено предаване на смисъла на текстовете, характерно за епохата на исихазма (срв. Лихачев 1958: 16-40 и Подскалски 2000: 301308).

Смята се, че доколкото този стил се тълкува като византийско влияние върху славянската книжнина и се отнася за периода след втората половина на XIV в., той се обуславя донякъде от въвеждането на новия Йерусалимски типик и промените в богослужението. Прието е литургичната реформа да се свързва и с реформа в правописа, проведена в българската книжнина от патриарх Евтимий. Но литургичната реформа няма пряка връзка с исихазма като направление във византийската религиозна доктрина $^{15}$, под съмнение е и правописната реформа (Станков 1999).

Високият житиен стил, основан на специфичен набор от топоси, библейски сравнения и реминисценции, следва модела на античните образци през Средновековието, но е присобен към каноните на християнската доктрина още през IV-VI в. Процесът на развитие на агиографския жанр към натрупване на варианти на художествена интерпретация във византийската литература води началото си още от IV в. и преминава през житийната реформа на Симеон Метафраст от X в., когато се преработват голям брой агиографски текстове (срв. Лопарьов 1910: 2-15, Трифунович 1974: 52-53, Иванова 1986), а славянските книжовници превеждат или заимстват от византийските жития, както от “дометафрастов” тип, така и от типа на по-късната Метафрастова житийна редакция (Иванова 1992).

По принцип жанрът на похвалното житие е образец още от Похвалното житие за Василий Велики, писано от Григорий Богослов (срв. Лопарев 1910: 16). Поради това житийно-панигиричният стил в сръбската средновековна книжнина от втората половина на XIII в. не бива да се отнася към новите тенденции на "исихастския" тип средновековно житие-

${ }^{14}$ Вж. сборниците Търновска книжовна школа, т. I, 1974; т. II, 1980; т. III, 1984; т. IV, 1985; т. V, 1994; т. VI, 1998; и т. VII, 2002; и още Динеков 1979, Станчев 1982, Русев 1983 и др.

15 За особеностите на исихазма като философско-теологична доктрина вж. най-общо Прохоров 1968 и Майендорф 1974. 
описание. Сръбските пространни жития от края са XIII в. представят и доразвиват ранната агиографска традиция, и едва ли са проява на "новите житийно-панегирични тенденции" в южнославянските литератури (вж. Иванова 1980).

Във връзка със сръбската агиография определението “плетение словес" най-често се отнася към стила на житиеписеца Доментиян. По отношение на стилистичните влияния в неговите жития са публикувани множество изследвания. П. Попович (1959: 219-220) проследява агиографските топоси и вероятните византийски образци, които са повлияли Доментияновите жития. Вл. Чорович (1921: 32-33) посочва приемствеността между Доментиян и Данило по отношение на образи и библейски цитати, и определя произведенията на двамата сръбски агиографи като “чисто риторични жития", разработени по напълно еднакъв образец (а именно византийския метафрастов модел - б.м.).

За стила на Доментиян се е наложило мнението, че той използва разгърнати риторични и поетични фигури в сложни композиционни цялости, с чести и дълги библейски аналогии, парафрази и реминисценции, натрупани в обширни пасажи (срв. Богданович 1980: 158-159). Изводът на Д. Богданович (1981: 338), че стилът на Доментиян е свойствен на византийската панигирично-агиографска литература, а през XV в. става популярен и в Русия благодарение на второто южнославянско влияние ${ }^{16}$, има известни основания. Действително още от Стефан Първовенчани в ранната сръбска агиография се налага по-пищен риторичен стил на изображение, свързан с възхвалата на владетеля-първосветец. В житията, писани от Доментиян, риторично-панигиричният патос преобладава. Стилът се развива в посока на натрупване на риторични стилистични фигури за възхвала на изобразяваните светци. Линията на писмена идеализация е последователно развита с многословни библейски реминисценции и теологични тиради. В случая обаче не би трябвало да се говори за ранна поява на стила "плетение словес" в сръбската агиография, тъй като Доментияновите жития са писани по примера на най-добрите византийски образци, които са му били достъпни в светогорския манастир Хилендар. Доментиян е изграждал произведенията си според установената вече във византийската практика богата метафорика и символика и според наложилата се в сръбската книжовна традиция топика за изобразяване на двамата сръбски първосветци.

Тук трябва да се изтъкне един значителен фактор за типологическото сходство в книжовната продукция на православните славяни, а именно контактите между славянските монаси-книжовници от манастирската общност на Атон с другите манастирски книжовни центрове и обменът на

\footnotetext{
16 За второто южнославянско влияние в Русия и свързаните с него нови тенденции в руската книжнина през посочения период вж. само Лихачев 1958, Станков 1992 и цитираната там литература.
} 
писмени паметници. През цялото Средновековие Света гора е центърът на оживена книжовна дейност и общуване между византийските и славянските книжовници ${ }^{17}$.

Затова е напълно логично хилендарските монаси от втората половина на XIII и началото на XIV в., Доментиян и Теодосий, да пренесат чрез произведенията си в сръбската литература влияния от византийската литература. В своите творби тези двама сръбски житиеписци доразвиват риторичната тенденция за идеализация на сръбските първосветци (започнала с ЖССП) - натрупват все повече библейски цитати и аналогии, извеждат на преден план приповдигнатия панигиричен патос в интерпретацията на житийните факти и образи, добавят дълги пасажи с теологични беседи, епистоларни елементи и описват множество посмъртнии чудеса на светците. Но като цяло агиографските произведения на Доментиян и Теодосий се вписват в рамките на византийската "метафрастова" поетика и в традицията на създадените преди това жития за двамата сръбски първосветци.

В заключение трябва да се подчертае значението на виенските ръкописи за по-пълното осветляване на творчеството на двамата хилендарски книжовници Доментиян и Теодосий. Съществуващите издания на текстовете с житията за двамата сръбски първосветци са от края на XIX в. и са недостъпни в повечето книгохранилища, а най-ранният сръбски ръкопис от XIV в., с преписи на житията за св. Сава от Теодосий и за св. Симеон от Доментиян, както и с общата похвала за двамата светци от Теодосий, все още чака своето издание (подобно на ръкописа № 17 от НБС, от който е издадена само общата похвала).

\footnotetext{
${ }^{17}$ Предполага се, че още през Х в. (919 г.) на Атон е основан първият славянски манастир - българският манастир Зограф, в първите десетилетия на XI в. руския манастир Ксилург и през XII в. (1122 г.) - манастирът Св. Пантелеймон. Повечето атонски манастири са създадени с помощта на византийските императори като царски обители. Затова свидетелстват и дарителските владетелски грамоти. Сръбският манастир на Света гора също е строен с ктиторството на сръбския владетел Стефан Неманич (св. Симеон). Веднага след основаването му в края на XII в. Хилендар се превръща в средище на сръбската средновековна книжнина и запазва тези си функции векове наред. От Хилендар водят началото си първите сръбски култове, там са творили най-продуктивните сръбски средновековни автори от XIII в. В православната монашеска общност на Атонския полуостров са извършени и множество преводи на средновековните византийски автори, на богослужебна и църковно-правна книжнина. От там чрез руски и сръбски преписи се разпространява и съхранява оригиналната старобългарска книжнина на Златния век (вж. Мошин 1947 и 1963, Дуйчев 1963: 128-129 и А.-Е. Тахиаос 1977).
} 
Ли те р ат ур а

Ангелов 1983:

Башич 1924:

Биркфелнер 1975:

Богданович 1970:

Богданович 1978:

Богданович 1980:

Богданович 1981:

Бойчевич 1939:

Брайович 1984:

Вулович 1885:

Вулович 1894:

Даничич 1860:

Даничич 1865:

Динеков 1979:

Динич 1959:

Дуйчев 1963:

Зееман 1988:

Иванов 1931:

Иванова 1980:

Иванова 1986:

Иванова 1992:

Измирлиева 1994:

Йованович 1973:

Йованович 2000:
Б. Ангелов, Старобългарско книжовно наследство, София

М. Башић, Старе српске биографије, Београд

G. Birkfellner, Glagolitische und kyrillische Handschriften in Österreich, Wien

Д. Богдановић, Предговор, в: Старе српске биографије, Београд, 5-19

Д. Богдановић, Нове тежње у српској књижевности првих децења XIV века, в: Византијска уметност почетка XIV в., Београд, 91-103

Д. Богдановић, Историја старе српске књижевности, Београд, 169-175

Д. Богдановић, Српска књижевност на путевима самосталног стварања, в: Историја српског народа, Београд, 328-340

М. Бојчевић, Ко је писао службу св. Петра Коришког, Гласник југословенског професорског друштва 20/2, 132-147

И. Брајовић, Стилско јединство у службама Теодосија Хиландараца, Зборник Матице српске за књижевност и језик $32 / 2,253-265$

Св. Вуловић, Понешто о биографијама XIII-ог века, Годишњица Николе Чупића 7, 90-135

Св. Вуловић, Понешто о биографијама XIII-ог века, Годишњица Николе Чупића 14, 230-250

Ђ. Даничић, Живот светога Саве, написао Доментијан (= Теодосије), Београд

Ђ. Даничић, Живот светога Симеуна и светог Саве, написао Доментијан, Београд

П. Динеков, Търновската книжовна школа в развитието на българската литература, в: Похвала на старата българска литература, София, 242-258

М. Динић, Доментијан и Теодосије, Прилози за књижевност, језик, историју и фолклор 25/1-2, 5-12

Ив. Дуйчев, Центры византийско-славянского общения и сотрудничества, Труды отдела древнерусской литературы $19,107-129$

K.-D. Seemann, Gattung, Gebrauchsfunktion und Schreibart in der altrussischen Literatur, in: Slavistische Studien zum X Internationalen Slavistenkongress in Sofia 1988, 569-580

Й. Иванов, Български старини из Македония, София (фототипно издание 1970)

Кл. Иванова, Житийно-панегиричното наследство на Търновската книжовна школа в балканската ръкописна традиция, в: Търновска книжовна школа, т. II, София, 193-214

Кл. Иванова, Житията в старата българска литература, в: Стара българска лиитература. Житиеписни творби, София, 5-34

Кл. Иванова, Метафрастовата житийна редакция, в: Старобългарската литература. Енциклопедичен речник, съставител Д. Петканова, София, 267-268

V. Izmirlieva, Stories and Names: Modes of Eastern Orthodox Rhetoric of Sainthood, Palaeobulgarica XVIII/3, 36-47

Т. Јовановић, Похвала светоме Симеону и светоме Сави Теодосија Хиландараца, Књижевна историја 5/25 (1972/73) 703-778

Т. Јовановић, Препис извода хиландарског типика у збирци румунске академије наука, в: Међународни научни скуп, 
Кашанин 1975: Костич 1933:

Костич 1934:

Лихачев 1958:

Лопарьов 1910:

Майендорф 1974:

Мошин 1939:

Мошин 1947:

Мошин 1958:

Мулич 1963:

Мулич 1965a:

Мулич 1965б:

Мулич 1966:

Мулич 1968:

Новакович 1879:

Новакович 1884:

Подскалски 2000:

Попович 1959:

Пролович 1986:

Протич 1897:

Прохоров 1968:

Розанов 1911:

Радойчич 1954:

Радойчич 1931:
Осам векова Хиландара, САНУ, књ. ХCV, Одељење историјских наука, књ. 27, Београд, 193-201

М. Кашанин, Српска књижевност у средњем веку, Београд

Д. Костић, Је ли Доментијан био ученик Сави и сапутник по светим местима?, Гласник југословенског професорског друштва 13/10, 934-935

Д. Костић, Кад је Теодосије писао живот и службу Петра Коришког?, Богословље 9/4, 371-382

Д. С. Лихачев, Некоторые задачи изучения второго южнославянского влияния в России, Москва

Хp. М. Лопарев, Византійскія Житія Святыхь VIII-IX вв., Византійскій временник 17/1-4, 1-224

И. Ф. Майендорф, О византийском исихазме и его роли в культурном и историческом развитии Восточной Европы в XIV в., Труды отдела древнерусской литературы 29, 291305

Вл. Мошин, Старац поп Теодосије и хиландарска "братија начелна", Јужнословенски филолог 17, 189-200

Вл. Мошин, Русские на Афоне и русско-византийские отношения в XI-XII вв., Byzantinoslavica 9, 55-85

Вл. Мошин, Датировка рукописей из собрания А. Ф. Гильфердинга, Труды отдела древнерусской литературы 15, 414415

M. Mulić, Srpsko „pletenije sloves“ do XIV-og stoleća, Radovi zavoda za slavensku filologiju 5, 28-106

М. Мулић, Плетеније словес и исихазам, Радови завода за славенску филологију 7, 141-156

М. Мулић, Стил српских средњовековних животописаца XIII и XIV века, в: Стара књижевност, прир. Ђ. Трифуновић, Београд, 197-205

М. Мулић, Византијска културно-књижевна традиција као база славенске књижевности, Филолошки преглед 1-4, 71-89 M. Мулич, Сербские агиографы XIII-XIV вв. и особенности их стиля, Труды отдела древнерусской литературы 7, 141156

Ст. Новаковић, Теодосија мниха Хилендараца похвала св. Симеону и Сави, Старине 11, 153-164

Ст. Новаковић, Теодосија мниха Хилендараца дјело о Петру Коришком, Старине 14, 9-34

G. Podskalsky, Theologische Literatur des Mittelalters in Bulgarien und Serbien (865-1459), München

П. Поповић, Доментијан, Прилози за књижевност, језик, историју и фолклор 25/3-4, 209-225

J. Проловић, Српски рукописи XIII и XIV века у Бечу и манастир Хиландар, Хиландарски зборник 6, 163-269

П. Протић, Старе српске биографије, Београд

Г. М. Прохоров, Исихазм и общественная мысль в Восточной Европе в XIV в, Труды отдела древнерусской литературы 23, 86-108

С. П. Розанов, Источники, время составления и личность Феодосиевской редакции Жития Саввы Сербскаго, Известия отделения русского языка и словесности 16/1, 136-184

Ђ. Сп. Радојчић, О старом српском књижевнику Теодосију, Историјски часопис 4 , 13-42

Н. Радојчић, Теодосијеви погледи на друштво и државно уређење Србије (= Расправа знанственог друштва 9), Љубљана 
Радойчич 1956:

Русев 1983:

Сречкович 1898:

Станоевич 1929:

Станков 1992:

Станков 1999:

Станкова 2003:

Станкович 1998:

Станчев 1982:

Тахиаос 1977:

Трифонова 1999:

Трифунович 1963:

Трифунович 1965a:

Трифунович 1965б:

Трифунович 1970:

Трифунович 1973 :

Трифунович 1974:

Трифунович 1978:

Хафнер 1964:

Църнич 1981:

Чорович 1921:

Чорович 1936:

Чорович 1965:

Шафарик 1831:

Шмаус 1963:
Н. Радојчић, Два Теодосија Хиландараца, Глас САН 218, 125

П. Русев, Естетика и майсторство на писателите от Евтимиевата школа, София

П. Сречковић, Творенија Доментијана и Теодосија, Споменик СКА 33, 119

Ст. Станојевић, Када је Теодосије писао житије светог Саве, Јужнословенски филолог 7 (1928/9) 201-204

Р. Станков, Второто южнославянско влияние в Русия през XIV-XV в., Годишник на СУ, ФСФ, 1-2/84, 69-106

Р. Станков, Исихазмът, стилът "плетение словес" и езиковоправописната реформа на патриарх Евтимий, София

P. Станкова, Библейски топоси в ранните служби за сръбски и български светци в ръкописи от XIII в., Palaeobulgarica XVII/ 4, 62-84

Р. Станковић, Рукописне књиге манастира Савине. Водени знаци и датирање, Археолошки прилози 20, 265-367

Кр. Станчев, Търновската книжовна школа и развитието на агиографските жанрове, в: Руско-балкански културни връзки през Средновековието, София, 207-216

A.-E. Tachiaos, Mount Athos and the Slavic Literatures, Cyrillomethodianum 6 , Thessalonique, 1-35

Р. Трифонова, Типологически паралели между българската и сръбската агиографска продукция през XIII в., Литературна мисъл 1, 110-131

Ђ. Трифуновић, Доментијан, Београд

Ђ. Трифуновић, Прилог проучавању реторске ритмичности у старој српској и старој руској књижевности, Књижевност и језик $3,67-72$

Ђ. Трифуновић, Доментијан песник светлости, в: Стара књижевност, прир. Ђ. Трифуновић, Београд, 331-353

Ђ. Трифуновић, Белешке о делима у Србљаку, в: О Србљаку. Студије, Београд, 279

Ђ. Трифуновић, Уз поновно издање Теодосијевог живота светога Саве, в: Теодосије Хиландарац, Живот светога Саве Изд. Ћ. Даничића, прир. и предг. Ђ. Трифуновић, Београд

Ђ. Трифуновић, Азбучник српских средњовековних књижевних појмова, Београд (II изд. 1990)

Ђ. Трифуновић, Теодулов препис Теодосијевог живота светог Саве, Хиландарски зборник 4, 99-107

St. Hafner, Studien zur altserbischen dynastischen Historiographie (= Südosteuropäische Arbeiten 62), München

Л. Црнић, О атрибуцији средњовековских ћирилских рукописа, в: Текстологија средњовековних југословенских књижевности, САНУ, Научни скупови, књ. Х, Одељење језика и књижевности, књ. 2, Београд, 339, 352-354

Вл. Ћоровић, Доментијан и Данило, Прилози за књижевност, језик, историју и фолклор 1, 21-33

Вл. Ћоровић, Мећусобни одношај биографијама Стефана Немање, Светосавски зборник 1, 13-38

Вл. Ћоровић, Доментијаново књижевно дело, в: Стара књижевност, прир. Ђ. Трифуновић, Београд, 319-330

P. J. Safarik, Übersicht der vorzüglichen schriftlichen Denkmäler älterer Zeiten bei den Serben und anderen Südslaven, Wiener Jahrbücher 1831 (= Летопис Матице српске 68, 1845)

A. Schmaus, Die literaturhistorische Problematik von Domentijans Sava-Vita, Opera Slavica, Bd. IV (= Slavistische Studien 
zum V. Internationalen Slavistenkongreß in Sofia 1963), Göttingen, 121-142

Шпадиер 2000: И. Шпадијер, Трагом светогорских преписа Теодосијевих дела, в: Међународни научни скуп, Осам века Хиландара. Историја, духовни живот, књижевност, уметност и архитектура, уред. В. Кораћ, Београд, 381-386

Щавлянин-Джорджевич - Паич-Грозданович - Цернич 1986: Л. Щавлянин-Ђорџевић - М. Пајић-Гроздановић - Л. Цернић, Опис ћирилских рукописа Народне библиотеке Србије, књ. 1, Београд

Юхас-Георгиевска 1995: Љ. Јухас-Георгиевска, Поговор, в: Хиландарски типик. Рукопис CHIL AS 156. Прир. Д. Богдановић, Београд

Ягич 1867:

V. Jagić, Historija književnosti naroda hrvatskoga i srpskoga (= Djela Vatroslava Jagića 4), Zagreb, 344-345

Ягич 1873: $\quad$ V. Jagić, Opisi i izvodi iz nekoliko južnoslovenskih rukopisa. Starine V, 3-288

Прило же н и е

За повече яснота по въпроса за времето на написването на двете жития прилагам известните ми до сега много сходни приписки от двата виенски ръкописа, които можах да сравня по време на специализацията ми в Славистичния институт на Виенския университет през 2002 г. ${ }^{18}$ с приписката от Петербургския ръкопис, която предавам според изданието на В. Ягич.

I. Приписката от ръкопис РНБ, Гильф. № 54 от 1420/35 г., според Ягич (1873: 11-12):

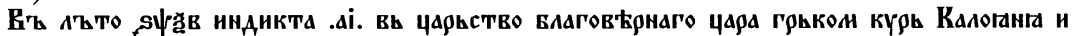
вь дни санод

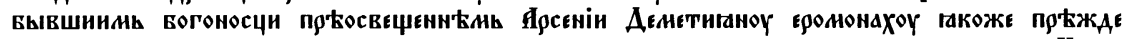

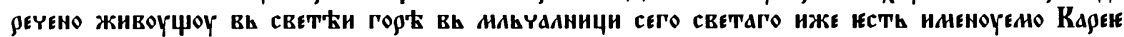

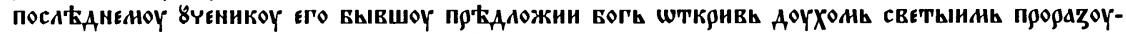

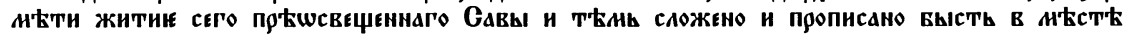

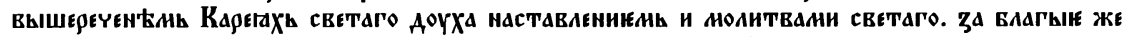

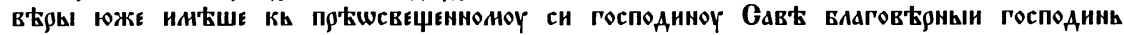

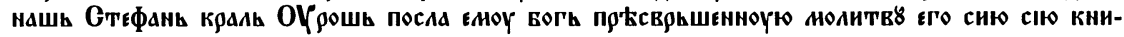

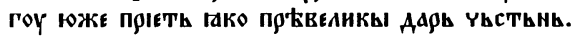

II. Приписката от Cod. slav. № 25 на Австрийската национална библиотека във Виена (л. 245r):

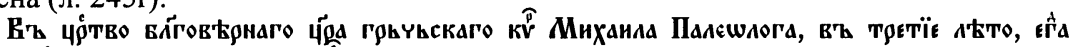

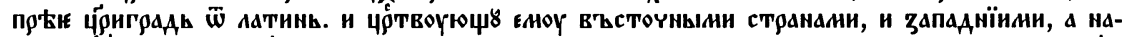

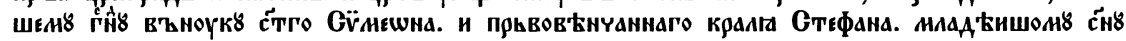

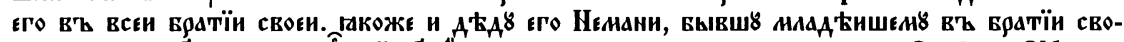

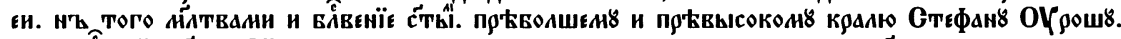

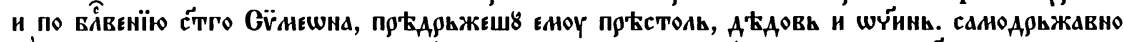

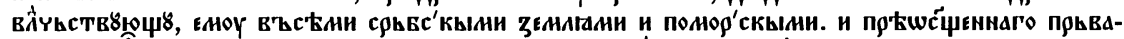

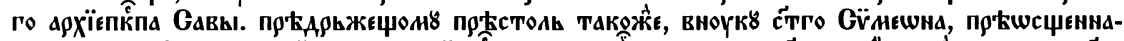

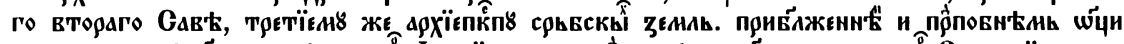

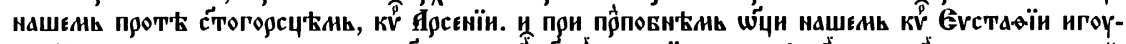

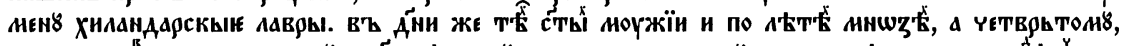

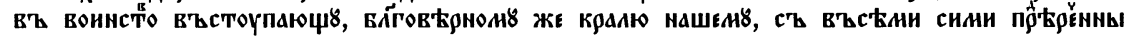

${ }^{18}$ Специализацията ми беше любезно субсидирана от Австрийския институт за Източна и Югоизточна Европа в София. 


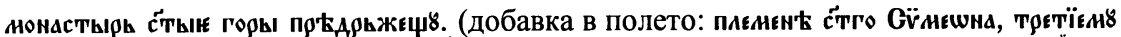

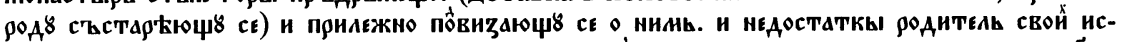

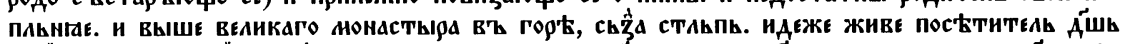

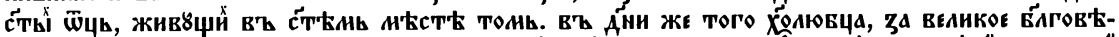

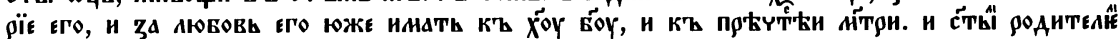

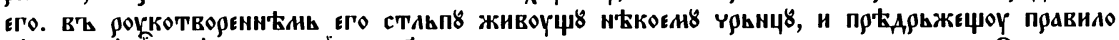

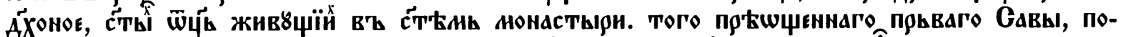

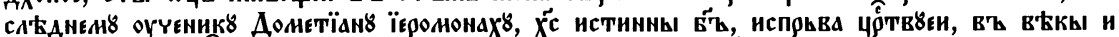

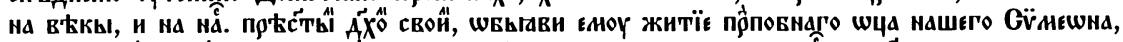

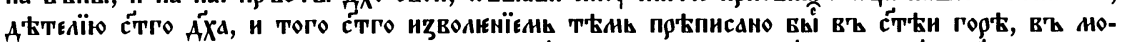

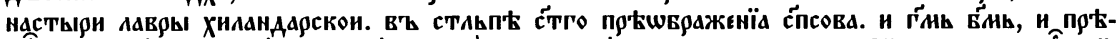
чтึั

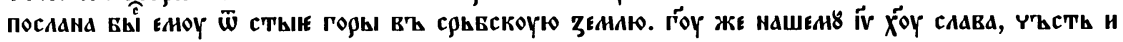

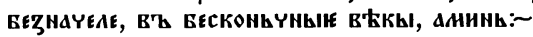

III. Приписката от Cod. slav. № 57 на Австрийската национална библиотека във Виена (лл. 121б-122б):

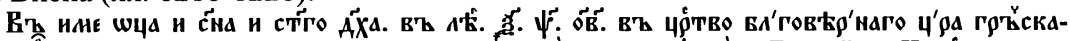

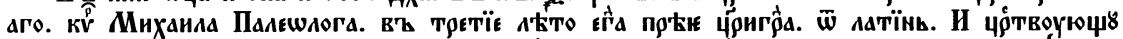

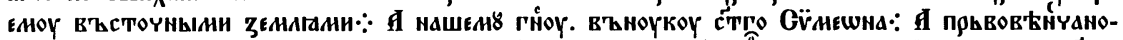

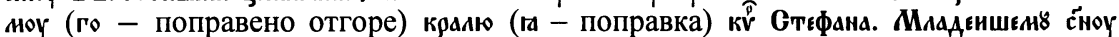

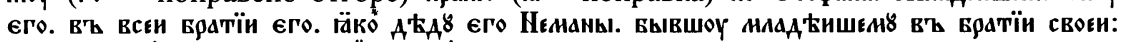

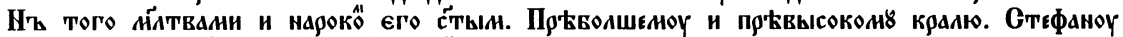

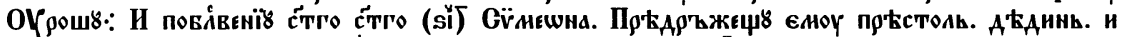

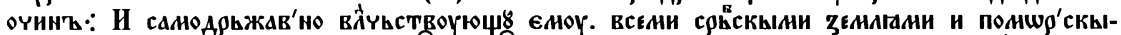

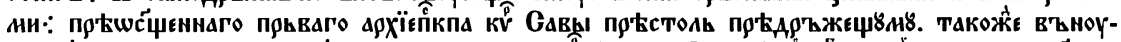

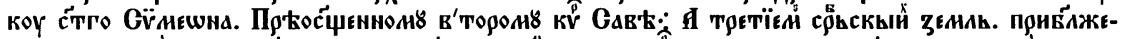

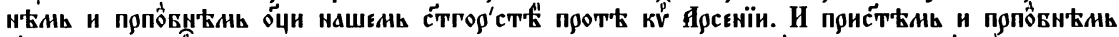

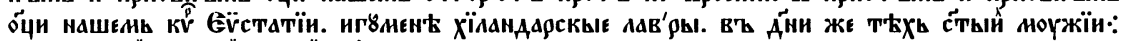

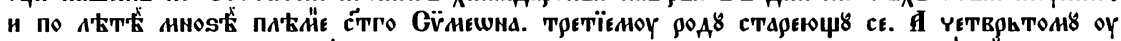

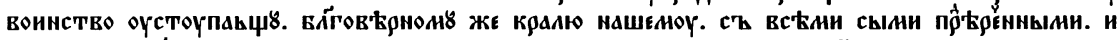

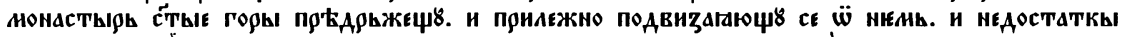

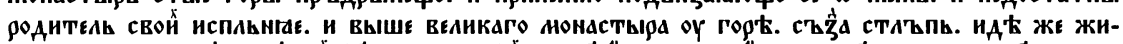

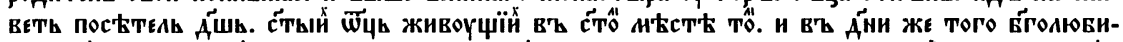

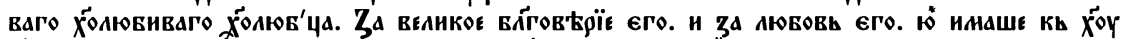

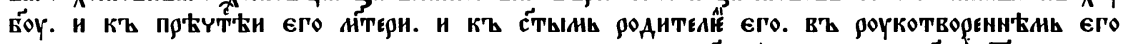

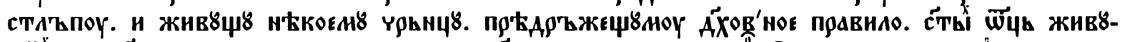

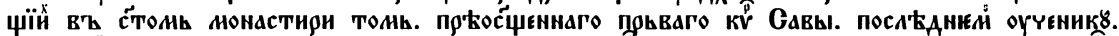

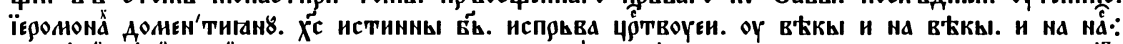

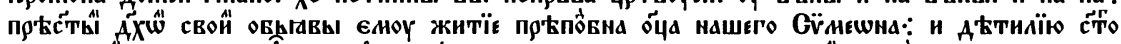

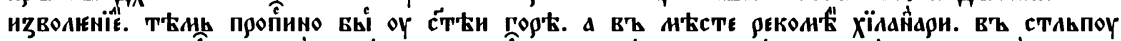

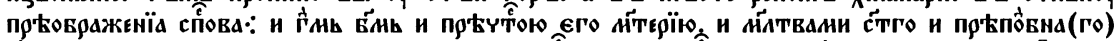

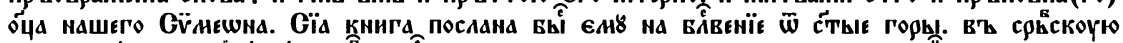

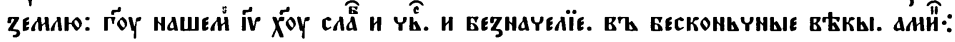

\section{$\mathrm{R}$ e $\mathrm{s}$ ü $\mathrm{m}$ e e}

Die Viten der Chilendar-Mönche Domentijan und Teodosij in den Wiener Handschriften und zur Frage des Stils „Pletenie sloves“ in der serbischen Hagiographie des 13. Jahrhunderts.

Um die serbischen Hagiographen Domentijan und Teodosij(e) und ihre Viten der Heiligen Simeon und Sava ranken sich noch zahlreiche Fragen. Unter besonderer Berücksichtigung der eingangs charakterisierten Wiener Zeugen (ÖNB, Codd. slav. 25, 57 und 131) geht der Artikel dreien dieser Fragen nach: 1. der Entstehungszeit der Viten, 2. der Lebens- bzw. Schaffenszeit der beiden Chilendar-Mönche; 3. dem Problem, ob 
die von serbischen Forschern getroffene frühe Zuweisung des Stils „Pletenie sloves“ zu hagiographischen Erzeugnissen wie den Domentijan-Viten gerechtfertigt ist. Im Anhang werden die (für die jeweiligen Protographen vorauszusetzenden) Nachschriften aus den Wiener Abschriften der bereits von V. Jagić publizierten Petersburger Abschrift (RNB, Gil’ferding № 54 a. 1420/35) gegenübergestellt. 